\title{
Do Derivative Instruments Play a Role in Performance Theory? The Turkish Closed-End Funds Case
}

\author{
Burak Pirgaip ${ }^{1}$ \\ ${ }^{1}$ Department of Banking and Finance, Cankaya University, Ankara, Turkey \\ Correspondence: Burak Pirgaip, Department of Banking and Finance, Cankaya University, Ankara, Turkey
}

Received: February 2, 2016

Accepted: February 18, $2016 \quad$ Available online: February 23, 2016

doi:10.11114/aef.v3i2.1349

URL: http://dx.doi.org/10.11114/aef.v3i2.1349

\begin{abstract}
Market prices of closed-end funds (CEF) deviate from their net asset values (NAV) which is known as "CEF puzzle". I attempt to show from the Turkish experience that CEF discounts/premia predict the corresponding CEF's future returns, in the light of managerial performance theory. But derivatives facet of the subject matter has not been uncovered so far. Therefore I hypothesize that performance of derivative user CEF are better estimators for discounts/premia than non-users. I show a significant positive relation between CEF discounts/premia and future NAV performance. However, this relation seems not to be more explicit for derivative user CEF than non-users.
\end{abstract}

Keywords: Closed-end funds; discount; managerial performance; derivatives

\section{Introduction}

Closed end funds [CEF], although they are operated in a similar manner, are idiosyncratic as opposed to other collective investment schemes (CIS), especially to their somewhat equivalents, i.e., open end funds (OEF), since CEF neither issue nor redeem their publicly-traded shares in order to meet investor expectations. This basic feature requires extrinsic factors associated with market supply and demand determine CEF prices rather than intrinsic or fundamental valuations, namely, Net Asset Value (NAV) calculations (Note 1).

On the other hand, the efficient market hypothesis states that assets ought to sell for their fundamental values. As NAV is the fundamental value of CEF, their prices should converge to their NAVs (Levy-Yeyati \& Ubide, 1998). However, contrary to this classic finance theory, CEF prices deviate from their NAVs in practice. Such deviations are called "premia", when the former is greater than the latter, and "discounts" vice versa. This premium/discount phenomenon is often referred as "the CEF puzzle" (Note 2).

A vast amount of literature has devoted a long lasting attention to the understanding of the CEF puzzle. But, I observe that CEF often trade at a discount rather than premium to their NAV and two groups of research intend to explain it, one following a traditional (rationality-based), while the other, a behavioral (irrationality-based) approach.

Traditional approach claims that discounts mainly stem from agency costs, tax liabilities and the illiquidity of assets in the portfolio. Excessive management fees, poor future NAV performance and ineffective fund organization may pave the way for discounts in accordance with agency problem approach (Dimson \& Minio-Paluello, 2002). Capital gains tax liabilities associated with fund assets may also reduce the liquidation value of the fund, which in turn causes discounts (Lee, Shleifer, \& Thaler, 1991). Large amounts of restricted stocks in the fund portfolio arguably may be overvalued in NAV calculation and this misvaluation may call for discount (Lee, Shleifer, \& Thaler, 1990). Behavioral approach, however, focuses on investor sentiment hypothesis and concur that rational investors that have unbiased expectations prefer CEF selling at discounts because of noise traders who make systematic forecasting errors irrationally. In so doing, rational investors are compensated for the noise trader risk (Lee, Shleifer, \& Thaler, 1991).

When I ignore the behavioral approach for a moment, one can easily argue that, by and large, all of the three components of traditional approach are closely linked to asset management, i.e. managerial performance (Note 3). I go beyond that and question whether or not derivatives, which can be utilized for either speculative or hedging purposes, make the situation more complicated.

Literature shows that derivatives are useful tools that allow fund managers to utilize information better and reduce transaction costs (Note 4). Although, usage of derivative has generated substantial attention from many communities, the 
linkage between actual derivative usage and fund performance is underexplored. It is anticipated that fund managers who use derivatives may improve fund performance, either through lower transaction costs or since the managers better utilize information. Nevertheless, Koski and Pontiff (1999) states that derivative use is unrelated to fund performance by showing that the risk-adjusted returns that accrue to the fund that use derivatives do not differ significantly from the returns for funds that do not use derivatives. Johnson and Yu (2004) conclude that differences in fund returns depend on fund type (e.g. equity funds, fixed-income funds) using derivatives or not. Fong et al. (2005) also reveals that the use of derivatives by institutional traders does not lead to significant differences in the fund performance between derivative users and non-users.

From the CEF point of view, I believe that derivatives would be an interesting research subject, which has not been touched on yet, in order to shed some light on existing foggy findings. Thereby, I intend to incorporate derivative use into the concept of CEF puzzle and try to figure out what the situation is when Turkish CEFs are considered.

First, I carry on the agency cost (Note 5) strand of the traditional approach. I make use of managerial performance hypothesis under which discounts/premia are attributed to investors' rational expectations of the inferior investment skills of fund managers. This assumes that investors obtain sufficient information to form expectations regarding the future investment decisions of the fund manager (Chay \& Trzcinka, 1999). In line with that, I expect that the market price of CEF shares reflects investors' expectations of the CEF's managerial performance in the future. Second, I expect that CEF portfolios whose managers use derivatives should demonstrate improved performance relative to non-users. Therefore, I anticipate a stronger positive (negative) relation between the premium (discount) of derivative user CEF and its future NAV performance than non-users'.

I start with a simple logistic regression analysis in order to explore what causes CEF discounts. I find that an increase in derivative use leads to CEF discounts being less likely to occur. However, this situation is exactly the opposite when derivative user CEFs are heavily equity investors at the same time. Then, I focus on the relationship between CEF performance and discounts/premia with respect to derivative use. I portray that derivative user CEFs are losers when compared to non-users if they are trading at discount. Lastly, I examine the relationship between discounts and future performance conditional on derivative usage and infer that performance of derivative user CEFs is not better estimators for discounts/premia than non-users.

The rest of this paper is organized as follows. In section 2, I briefly review managerial performance hypothesis and derivatives' role therein. In section 3, I describe Turkish CEF and derivatives market and the process of data collection and sampling. Section 4 displays the outcomes of my empirical analyses and Section 5 concludes.

\section{Hypothesis}

\subsection{Main Theme: Managerial Performance Hypothesis}

The managerial performance theory (Malkiel, 1977) states that discounts/premia vary with the skills of fund managers. Specifically, CEFs that charge high fees or invest in underperforming stocks sell at a large discount from NAV. Discounts are associated with investors' rational expectations of bad asset management skills in terms of both imprudent investment decisions and misappropriate use of fund portfolio (Chay \& Trzcinka, 1999). If a manager is perceived to be highly skilled at stock selection or market timing, investors bid up the price of fund shares, and the CEF trade at a premium. Similarly, if a fund's expense ratio is unreasonably high, it should sell at a discount (Richard \& Wiggins, 2000).

To empirically test managerial performance hypothesis, one can try to show that historical fund performance determines future NAV discounts/premia. However, no relation was found between fund discounts and either historical performance or management fees (Malkiel, 1977, 1995). Besides, one can also try to examine the relation between discount/premia and future performance. In that respect, while Pontiff (1994) finds no evidence that premia predict future NAV returns, Chay and Trzcinka (1999) supports that higher premia forecast superior NAV performance.

Although, this seems to be a kind of chicken and egg problem, assuming rational expectations, it would be more appropriate to check for a relation between discounts/premia and future NAV performance of funds rather than past or current performance (Lee, Shleifer,\& Thaler, 1991). Therefore, I follow the second point of view above and assume that investors obtain sufficient information in order to form outside expectations (future performance/price) from inside of the fund (discount/premium) regarding manager's investment behavior. Accordingly, my first hypothesis is as follows;

Hypothesis 1: "There is a positive relation between the premium of CEF and its future NAV performance."

With respect to performance, I prefer to consider net managerial performance, defined as the gross managerial performance resulting from the investment decisions of management minus all expenses incurred by management and other outflows not accruing to the investors (Chay \& Trzcinka, 1999). 


\subsection{Complementary Theme: Derivatives' Role in Managerial Performance Hypothesis}

Given the explosive growth in derivatives, it would be crucial to be better informed about how derivatives are used by and affect the performance of funds. With regards to the potential use of derivatives, hedge funds are the most prominent ones amidst other CIS. Hedge funds are characterized by strong performance incentives, which in some cases lead to excess risk taking under some conditions. Derivatives are flexibly used in such cases in order to enhance returns and reduce systematic risk. It is, however, legally limited for OEF to use derivatives insomuch that these regulatory restrictions lead to dramatic differences between hedge funds and them (Ackermann \& Ravenscraft, 1998). This may also appear to handicap OEF performance relative to hedge funds (Ackermann, McEnally, \& Ravenscraft, 1999). On the other hand, CEF are relatively exempt from these restrictions (Cherkes, Sagi, \& Stanton, 2008).

At that point, whether derivatives are used by CEF managers to hedge, to speculate, or to reduce market frictions such as transaction costs, or information costs (Garcia-Appendini \& Rangel-Hilt, 2009), I expect that CEF portfolios whose managers use derivatives demonstrate improved performance relative to non-users. Thus, I anticipate a stronger positive (negative) relation between the premium (discount) of derivative user CEF and its future NAV performance than non-users'. Therefore, my second hypothesis is as follows;

Hypothesis 2: "There is a stronger positive relation between the premium of derivative user CEF and its future NAV performance.

\section{Data}

\subsection{CEF in Turkish Capital Markets}

CIS in Turkey have developed since the introduction of the Capital Markets Law in 1981 and OEF are the most numerous ones as these have been being created since 1987. The sector comprising both OEF and CEF, had assets under management of around USD 25 billion at the end of 2011, with OEF constituting nearly 70\% of this value.

There are several varieties of CEF: (i) securities investment trust (SCITS), (ii) venture capital investment trust (VCITS) and (iii) real estate investment trust (REITS). SCITs are akin to OEF in terms of their investment strategies. However, VCITs and REITs are specialized in private equity and real estate business respectively and they have unique regulations. Such characteristics make them differentiated from SCITs in CEF category.

On the other hand, derivatives have been in Turkish capital markets since February, 2005. An organized derivatives market offers short-term debt, equity indices, foreign exchange and commodity future contracts, and equity and currency options. The market had a total trading volume of over 263 billion USD (74 million contracts) in 2011. Capital Markets Board of Turkey (CMB) allowed CEF to invest in derivatives in the derivatives market also in 2005.

Although, derivatives market began to operate as of 2005, due to the uncertainties in tax regime for derivatives, transactions were rare during the start-up phase. After the enactment of an amendment to Income Tax Law in 2006, which stated derivatives invested by CIS are tax free, derivative transactions were dramatically increased. On the other hand, a CMB regulation dated 2011, forced SCITs to quit from business by means of hard-to-adapt provisions and the number of them decreased by $20 \%$ and $50 \%$ in 2011 and 2012 respectively. Indeed some of them changed their business by turning into REITs, VCITs or some of them merged with other companies.

Considering the aforementioned conditions, I set the time period as 01.01.2007-31.12.2010 in my study. Mainly CMB sources are used in the data collection and I also support these data with statistical information publicly presented by TKYD (Note 6) and FINNET (Note 7).

\subsection{CEF Definition and Sampling}

I exclude REITs and VCITs from my humble 'CEF definition' in mind, since they neither provide daily NAV (Note 8) or even market price (Note 9) information nor trade (Note 10) in derivatives. In contrary, SCITs fit well in my model in terms of their daily available NAV information and flexibility in derivative use (both to hedge against risk and to acquire risk by speculation). Hence, I define Turkish CEF as SCITs only. In order to construct the final sample I follow the approach figured as below: 
Table I. Sample Selection in Line with the CEF Definition

\begin{tabular}{|c|c|c|c|c|c|c|}
\hline \multirow[t]{2}{*}{ CEF } & \multicolumn{4}{|c|}{ CEF Population } & $\begin{array}{c}\text { CEF Sample } \\
\text { (Alive) }\end{array}$ & $\begin{array}{c}\text { CEF Sample } \\
\text { (Derivative Use) }\end{array}$ \\
\hline & 2007 & 2008 & 2009 & 2010 & & $7-2010$ \\
\hline SCITs & 33 & 34 & 33 & 31 & 29 & 24 \\
\hline REITs & 13 & 14 & 14 & 21 & & \\
\hline VCITs & 2 & 2 & 2 & 2 & & \\
\hline Total & 48 & 50 & 49 & 54 & & 24 \\
\hline
\end{tabular}

Out of 31, the number in the last period, i.e. 2010, I firstly consider all SCITs exist backwards in 2007, 2008, 2009, and 2010. After getting a number of 29 , I analyze their daily portfolios to determine the status of CEF in terms of derivative use. I realize that some CEF managers have decided to switch from user to non-user status or vice versa year by year. So, I exclude hazy managers and arrive a final sample of 24 pure derivative user/non-user CEF.

\section{Results}

\subsection{Descriptive Statistics}

Before testing my hypothesis, I summarize the basic features of the data in my study. I use univariate (i.e. distribution, central tendency, and dispersion) analysis in order to present a brief fact sheet of CEF and their derivative use in Turkish capital markets. Firstly, I analyze data for $29 \mathrm{CEF}$ regardless of their manager style so as to understand the periodical changes in derivative use. Then, I integrate the results derived from my final sample of $24 \mathrm{CEF}$ with this analysis.

Table II points out that derivative usage has gradually increased year over year which makes us think that derivatives become more preferable $(55,2 \%$ to $68,9 \%)$ instruments in portfolio management as compared to the past. Furthermore, it seems that CEF managers prefer (4 year average use is around $78 \%$ for 29 CEF; $81 \%$ for 24 CEF) to use derivatives having equity indices as underlying assets. Especially, in 2010, 90\% (marginal increase in EI in 2010 is 4, which means that 4 of 5 managers used equity derivatives) of the managers shifted from non-user to user status solely by equity derivatives.

\begin{tabular}{|c|c|c|c|c|c|c|}
\hline \multirow{2}{*}{$\begin{array}{l}\text { Category } \\
\text { (Year) }\end{array}$} & \multirow{2}{*}{$\begin{array}{l}\# \text { of } \\
\mathrm{CEF}\end{array}$} & \multicolumn{4}{|c|}{$\begin{array}{l}\#(\%) \text { of } \\
\text { user CEF }\end{array}$} & \multirow{2}{*}{$\begin{array}{c}\#(\%) \text { of } \\
\text { non-user CEF }\end{array}$} \\
\hline & & EI* & $\mathrm{FX}^{*}$ & Both & Total & \\
\hline 2007 & 29 & $11(37.9 \%)(68.8 \%)$ & - & $5(17.3 \%)(31.2 \%)$ & $16(55.2 \%)$ & $13(44.8 \%)$ \\
\hline 2008 & 29 & $12(41.3 \%)(70.1 \%)$ & - & $5(17.3 \%)(29.4 \%)$ & $17(58.6 \%)$ & $12(41.4 \%)$ \\
\hline 2009 & 29 & $15(51.7 \%)(83.3 \%)$ & $1(3.5 \%)(5.6 \%)$ & $2(6.9 \%)(11.1 \%)$ & $18(62.1 \%)$ & $11(37.9 \%)$ \\
\hline 2010 & 29 & $18(61.9 \%)(90 \%)$ & $1(3.5 \%)(5.0 \%)$ & $1(3.5 \%)(5.0 \%)$ & $20(68.9 \%)$ & $9(31.1 \%)$ \\
\hline 2007 & 24 & $11(45.8 \%)(73.3 \%)$ & - & $4(16.7 \%)(26.7 \%)$ & $15(62.5 \%)$ & $9(37.5 \%)$ \\
\hline 2008 & 24 & $11(45.8 \%)(73.3 \%)$ & - & $4(16.7 \%)(26.7 \%)$ & $15(62.5 \%)$ & $9(37.5 \%)$ \\
\hline 2009 & 24 & $13(54.2 \%)(86.7 \%)$ & - & $2(8.3 \%)(13.3 \%)$ & $15(62.5 \%)$ & $9(37.5 \%)$ \\
\hline 2010 & 24 & $14(58.3 \%)(93.3 \%)$ & $1(4.2 \%)(6.7 \%)$ & - & $15(62.5 \%)$ & $9(37.5 \%)$ \\
\hline
\end{tabular}

* EI stands for equity index future contracts and FX stands for currency future contracts. Gross Sample of 29 CEF (including changes in user-status within the whole 4 year period.) Numbers in parentheses represent the percentage of CEF for a given derivative category in both total number of CEF and total number of derivative user CEF, respectively. Percentages of users and non-users in total number of CEF are also given in the rightest columns of the table.

One possible explanation is, as trading activity in the equity market expands, CEF managers may try to benefit from volatility in equity prices or to hedge their spot equity portfolio against price fluctuations by going short at the derivatives market. The sharp increase in the number of EI user (12 to 18) CEF by the last two years may be a proof for that, as 2009 and 2010 are the peak years of trading volume.

In order to figure out the factual situation in the derivatives market, I next analyze daily derivative transactions made by all CIS and carve my CEF's market share out. My analysis provides a general comparison between CIS and CEF with regards to underlying assets and position types (in terms of both number of contracts and volume of transactions).

In accord with Table III, most of CIS's derivative transactions are based on equities, rather than currency or etc., and 
their volume has a steady increase over years. Short positions, additionally, outweigh long ones, which is a sign of hedging purpose beneath derivative use. Interestingly, it is the opposite in the FX side (except for 2010), since greater long positions show speculative activity. It is no different for CEF's equity based derivative use, however CEF almost do not prefer FX futures. In fact, CEF's market share of EI use is considerably high (except for 2010) as opposed to other CIS, while FX use is negligible. Year 2010 seems to be different for CEF when compared with other periods, because although the volume of EI use increases, CEF market share (25.08\%) dramatically decreases. I think that this is due to the fact that other CIS (particularly pension funds) also began to use equity derivatives, the volume of which had tripled since 2009 .

Table III. Transactions in the derivatives market by CIS and CEF

\begin{tabular}{|c|c|c|c|c|c|c|c|c|c|c|c|c|c|c|}
\hline \multirow[b]{2}{*}{ Year } & \multirow[b]{2}{*}{ Contract } & \multicolumn{5}{|c|}{ CIS } & \multicolumn{5}{|c|}{ CEF } & \multicolumn{3}{|c|}{$\begin{array}{l}\text { Percentage of Derivative Use } \\
\text { by CEF (Volume) }\end{array}$} \\
\hline & & $\begin{array}{l}\text { Number of } \\
\text { long positions }\end{array}$ & $\begin{array}{c}\text { Number of } \\
\text { short } \\
\text { positions }\end{array}$ & $\begin{array}{l}\text { Volume of long } \\
\text { positions (USD) }\end{array}$ & $\begin{array}{l}\text { Volume of short } \\
\text { positions (USD) }\end{array}$ & TOTAL (USD) & $\begin{array}{c}\text { Number of } \\
\text { long } \\
\text { positions }\end{array}$ & $\begin{array}{c}\text { Number of } \\
\text { short } \\
\text { positions }\end{array}$ & $\begin{array}{l}\text { Volume of long } \\
\text { positions } \\
\text { (USD) }\end{array}$ & $\begin{array}{l}\text { Volume of short } \\
\text { positions (USD) }\end{array}$ & TOTAL (USD) & Long & Short & TOTAL \\
\hline \multirow{3}{*}{ ते } & FX & 237672.00 & 101956.00 & 189910840.29 & 72827552.29 & 262738292.57 & 23450.00 & 330.00 & 18689654.29 & 258591.43 & 18948245.71 & $9.84 \%$ & $0.36 \%$ & $7.21 \%$ \\
\hline & EI & 51594.00 & 1014423.00 & 174612698.57 & 3692577827.14 & 3867190525.71 & 19432.00 & 647938.00 & 64825581.43 & 2360661485.71 & 2425487067.14 & $37.13 \%$ & $63.93 \%$ & $62.72 \%$ \\
\hline & TOTAL & 289266.00 & 1116379.00 & 364523538.86 & 3765405379.43 & 4129928918.29 & 42882.00 & 647938.00 & 83515235.71 & 2360920077.14 & 2444435312.86 & $22.91 \%$ & $62.70 \%$ & $59.19 \%$ \\
\hline \multirow{3}{*}{$\stackrel{\infty}{\infty}$} & $\mathrm{FX}$ & 519504.00 & 178288.00 & 395772439.43 & 156512799.43 & 262738292.57 & 28594.00 & 136198.00 & 20039993.14 & 124065608.00 & 144105601.14 & $5.06 \%$ & $79.27 \%$ & $26.09 \%$ \\
\hline & EI & 116173.00 & 1853235.00 & 302960008.57 & 4934982517.14 & 3867190525.71 & 35426.00 & 1264076.00 & 84499357.14 & 3322600375.71 & 3407099732.86 & $27.89 \%$ & $67.33 \%$ & $65.05 \%$ \\
\hline & TOTAL & 635677.00 & 2031523.00 & 698732448.00 & 5091495316.57 & 4129928918.29 & 64020.00 & 1400274.00 & 104539350.29 & 3446665983.71 & 3551205334.00 & $14.96 \%$ & $67.69 \%$ & $61.33 \%$ \\
\hline \multirow{3}{*}{ छे } & $\mathrm{FX}$ & 769618.00 & 266323.00 & 693606527.14 & 257203270.86 & 950809798.00 & 26594.00 & 64674.00 & 22867266.86 & 65753498.57 & 88620765.43 & $3.30 \%$ & $25.56 \%$ & $9.32 \%$ \\
\hline & EI & 282413.00 & 2436135.00 & 872224220.00 & 16759609405.71 & 7631833625.71 & 11073.00 & 1670908.00 & 22928985.71 & 4497713918.57 & 4520642904.29 & $2.63 \%$ & $66.54 \%$ & $59.23 \%$ \\
\hline & TOTAL & 1052031.00 & 2702458.00 & 1565830747.14 & 7016812676.57 & 8582643423.71 & 37667.00 & 1735582.00 & 45796252.57 & 4563467417.14 & 4609263669.71 & $2.92 \%$ & $65.04 \%$ & $53.70 \%$ \\
\hline \multirow{3}{*}{$\stackrel{\circ}{\circ}$} & FX & 139161.00 & 721906.00 & 118793673.43 & 625978259.14 & 744771932.57 & 11250.00 & 315977.00 & 9589028.57 & 275952008.29 & 285541036.86 & $8.07 \%$ & $44.08 \%$ & $38.34 \%$ \\
\hline & EI & 1380706.00 & 3595869.00 & 6300906035.71 & 15342261395.71 & 21643167431.43 & 2522.00 & 1273243.00 & 11142494.29 & 5416623207.14 & 5427765701.43 & $0.18 \%$ & $35.31 \%$ & $25.08 \%$ \\
\hline & TOTAL & 1519867.00 & 4317775.00 & 6419699709.14 & 15968239654.86 & 22387939364.00 & 13772.00 & 1589220.00 & 20731522.86 & 5692575215.43 & 5713306738.29 & $0.32 \%$ & $35.65 \%$ & $25.52 \%$ \\
\hline
\end{tabular}

A comparison of $29 \mathrm{CEF}$ with all types of CIS trading in the derivatives market. The rightest three columns represent the percentage of volume of derivatives use by CEF among all types of CIS

Table IV shows the interrelationships between CEF variables given in Table III in a different way. Accordingly, the greatest average (mean: 9.570) and smallest dispersion [std.dev: 0.158, approximately 68\% (95\%) (99\%) of the short EI transaction volumes fall within the range of 9.412-9.728 (9.254-9.886) (9.096-10.044)] belongs to short equity positions upon years. Although its mean (7.229) is not as big as others, long currency positions come second by the help of its lower standard deviation (0.169). I can say that, CEF managers are more decisive about using short equity derivatives to hedge and long currency derivatives to speculate.

Table IV. CEF Volume of Derivatives by Type

\begin{tabular}{|c|c|c|c|c|c|}
\hline & & LongFX & LongEI & ShortFX & ShortEI \\
\hline 2007 & & 7.272 & 7.812 & 5.413 & 9.373 \\
\hline 2008 & & 7.302 & 7.927 & 8.094 & 9.521 \\
\hline 2009 & & 7.359 & 7.360 & 7.818 & 9.653 \\
\hline 2010 & & 6.982 & 7.047 & 8.441 & 9.734 \\
\hline Mean & & 7.229 & 7.536 & 7.441 & 9.570 \\
\hline Std. Dev. & & 0.169 & 0.408 & 1.376 & 0.158 \\
\hline \multirow{2}{*}{$68 \%$} & $\max$ & 7.397 & 7.944 & 8.817 & 9.728 \\
\hline & $\min$ & 7.060 & 7.129 & 6.065 & 9.412 \\
\hline \multirow{2}{*}{$95 \%$} & $\max$ & 7.566 & 8.352 & 10.194 & 9.886 \\
\hline & $\min$ & 6.892 & 6.721 & 4.689 & 9.254 \\
\hline
\end{tabular}




\begin{tabular}{|c|c|c|c|c|c|}
\hline \multirow{2}{*}{$99 \%$} & $\max$ & 7.734 & 8.760 & 11.570 & 10.044 \\
\hline & $\min$ & 6.723 & 6.313 & 3.313 & 9.096 \\
\hline
\end{tabular}

24 CEF's use of derivatives and their central tendencies. In the columns, the logarithmic versions of the volume of long and short positions are presented. e.g. LongFX stands for log volume of long currency positions.

Table V shows another summary of derivative usage, which constitutes the fundamentals of my research. It is observed that, a majority of CEF $(83.3 \%)$ trade at discount for all periods and derivative user CEF are the most prominent $(60 \%$ (Note 11)) ones (Note 12). Also, premia is more (75\% as opposed to $25 \%$ ) in derivative users relative to non-users. An additional interesting output is that the number of CEF trading at discount and premium is more $(62.5 \%)$ in the case of derivative users, which crystallizes my main question: Do derivatives relate with discounts/premia?

Table V. Summary of Derivative Use by CEF (Discount or Premium)

\begin{tabular}{cccc}
\hline $\begin{array}{c}\text { Category } \\
\text { (NAV vs. Price) }\end{array}$ & CEF & $\begin{array}{c}\#(\%) \text { of } \\
\text { user CEF }\end{array}$ & $\begin{array}{c}\#(\%) \text { of } \\
\text { non-user CEF }\end{array}$ \\
\hline Discount & $20(83.3 \%)$ & $12(60 \%)(80 \%)$ & $8(40 \%)(88.9 \%)$ \\
Premium & $4(16.7 \%)$ & $3(75 \%)(20 \%)$ & $1(25 \%)(11, .1 \%)$ \\
Overall & 24 & $15(62.5 \%)$ & $9(37.5 \%)$ \\
\hline
\end{tabular}

Final sample of 24 CEF (including only never-users and ever-users within the whole 4 year period.) Numbers in parentheses represent the percentage of CEF for a given category (i.e. 80\% of derivative user CEF trade at discount, that is $12 / 15$ or $60 \%$ of CEF trading at discount are derivative users, that is $12 / 20$.)

\subsection{Inferential Statistics}

My first inferential study includes a logit analysis modeling any possible effects of explanatory variables on the probability of discounts/premia as follows:

$$
\operatorname{logit}(p)=\alpha t+\beta 1 D E R+\beta 2 V O L+\beta 3 S I Z E+\beta 4 E Q T Y+\beta 5 E Q T Y * D E R
$$

Derivative use variable (DER) is expected to have an impact of discount/premia as data given in Table $\mathrm{V}$ above suggest. In addition, regulation requires derivative user CEF to establish internal control and risk management systems within their organizations and employ licensed and experienced portfolio managers, which potentially lead to an increase in costs. Hence, derivative user CEF would incur high expense ratios, which may call for discounts. Volume (VOL) is a measurement of trading activity, which gives us hint that as trade volume increases, likelihood of discounts also increases due to the overload of transaction costs. Size of the fund (SIZE) may also relate with discounts since CEF, whose market share is relatively high, would be a proxy for both transaction and employment costs. CEF investing equities (EQTY) would also increase the probability of discounts as they are exposed to market risk as opposed to bond funds. I lastly interact derivative user with equity investor funds (EQTY*DER) as an attempt to describe how the effect of derivative use depends on the level/value of equity investments.

Table VI points out the results of my logistic model. The findings imply that all variables are both individually and jointly highly significant (Note 13). Derivative use and volume have a negative effect on the probability of discounts while other variables have positive effects.

Table VI. Relation between Discounts and Derivative Use

\begin{tabular}{cccc}
\hline Variable & Coefficients & $p$ value & Odds Ratio \\
\hline Intercept & -0.9956913 & 0.000 & - \\
Derivative Use (DER) & -1.230268 & 0.000 & 0.2922142 \\
Volume (VOL) & -0.0001444 & 0.000 & 0.9998556 \\
Fund Size (SIZE) & 0.0009365 & 0.000 & 1.000937 \\
Equity Fund (EQTY) & -0.0214561 & 0.863 & 0.9787724 \\
Equity Fund * Derivative Use & 1.222753 & 0.000 & 3.396525 \\
Pseudo R ${ }^{2}$ & & 0.535 & \\
LR Stat $=3526$ & & 0.000 & \\
\hline
\end{tabular}

The table shows empirical findings of a logit analysis for CEF in which the dependent variable takes the value of 1 if the fund trades at discount and zero otherwise. Derivative use is a dichotomous variable that takes the value of 1 if the fund uses derivatives and 0 if it does not. Volume is the natural $\log$ of transaction volume of the fund. Fund size is the natural $\log$ of total fund assets. Equity fund is a dichotomous variable that takes 1 if the fund invests primarily in 
equities (higher than 50\%) and 0 if the fund invests primarily in bonds (higher than 50\%). The last one is the interaction variable. Year dummies are not reported. All of the variables are based on daily observations.

With this model, I can interpret the variable Volume and Fund Size in the usual way - a one percent increase in transaction volume yields a slight $(0.0001 \%)$ decrease and a one percent increase in fund's total assets yields a slight $(0.009 \%)$ increase in the odds of discounts. The effect of derivative use on discounts is e $e^{(-1.23)}=0.2923$, so it yields a $71 \%$ decrease in the odds of discounts. Interestingly, to be an equity investor CEF solely is not a determinant for discount/premium as it (EQTY) is the only variable that has an insignificant effect. The cause and effect relationship gets significant when such CEF use derivatives as an asset management strategy. So, given the interaction term, the net effect is $(-1.23+1.22) *$ EQTY If EQTY is 0 then the effect is -1.23 (which is DER coefficient), but if EQTY is 1 then the effect is $(-1.23+1.22)=-0.01$. In terms of odds ratios, I can say that the odds ratio for users is $\mathrm{e}^{(-0.01)}=0.99$. In this case, the effect of derivative use is more positive where the fund also invests in equities.

The logistic interaction term's odds can be interpreted as the difference between derivative users and non-users on the odds of discount/premium. More explicitly, the discounts odds for users investing mainly in equities in the spot market are approximately $240 \%$ greater than those for similar non-users.

Overall, derivative user equity investors CEF have more probability of discounts than non-user ones. Hence, the reason behind the majority of derivative users trading at discount might be the equity preference of managers in their portfolios. I think that, this preference might pave the way for shorting equities to hedge, rather than speculative trading, in the expense of getting higher returns and closing discount gap.

I still take the view that derivatives may provide the flexibility for the portfolio manager to make fund transactions less costly and to control risks associated with the market (Koski \& Pontiff, 1999). Hence, I anticipate that derivative user CEF achieve higher returns than non-users. In order to analyze this, I compute unconditional CAPM alpha, which is the intercept from the regression of the CEF's NAV return in excess of the risk-free return on the benchmark's return in excess of the risk-free return (Chay \& Trzcinka, 1999).

$$
r_{t}-r_{f t}=\alpha_{t}+\beta_{t} *\left(r_{m t}-r_{f t}\right)+u_{t}
$$

$\mathrm{rt}=\mathrm{CEF}$ return (Note 14) for month $\mathrm{t}, \mathrm{rft}=$ the risk-free rate

(Note 15) at month $\mathrm{t}, \mathrm{rmt}=$ the return on the TKYD indices $($ Note

16) for month t.

Table VII. Unconditional CAPM Alpha by Discount/Premium Category and Use of Derivatives

\begin{tabular}{|c|c|c|c|c|c|c|c|c|}
\hline \multirow{3}{*}{$\begin{array}{l}\text { Category } \\
\text { (NAV vs. Price) }\end{array}$} & \multicolumn{2}{|c|}{ Overall } & \multicolumn{2}{|r|}{ Users } & \multicolumn{2}{|c|}{ Non-Users } & \multicolumn{2}{|c|}{ Test of Differences } \\
\hline & & Mean & & Mean & & Mean & & \\
\hline & $N$ & Alpha & $N$ & Alpha & $N$ & Alpha & $t$-test & $p$-value \\
\hline Discount & 20 & -0.02587 & 12 & -0.02574 & 8 & -0.026062 & -1.99808 & $0.061 *$ \\
\hline Premium & 4 & -0.02481 & 3 & -0.02544 & 1 & -0.022926 & 2.768272 & 0.1095 \\
\hline Overall & 24 & -0.0257 & 15 & -0.02568 & 9 & -0.025714 & -0.09336 & 0.9265 \\
\hline
\end{tabular}

$\mathrm{r}_{\mathrm{t}}=$ CEF return for month $\mathrm{t}, \mathrm{r}_{\mathrm{ft}}=$ the risk-free rate at month $\mathrm{t}, \mathrm{r}_{\mathrm{mt}}=$ the return on the TKYD indices for month $\mathrm{t}$. Users and Non-Users refer to CEF that use and do not use derivatives. Test of differences shows whether mean variable estimates are equal for users and non-users.

According to Table VII, which reports the OLS results, overall, I find negative abnormal performance (-0.0257) for CEF and it is insignificant $(-0.09336)$ that the CEF is a derivative user or not. Thus, derivatives seem not to be associated with return.

However, my results are at odds when I consider discount or premium facts. The most underperforming category of CEF is the non-user CEF trading at premium (-0.022926). Alpha for the derivative user CEF in discount category (-0.02574) is greater than that of non-user CEF (-0.026062), and the difference seems to be statistically significant at $10 \%$ level. This relationship is about the opposite for the premium category. I infer that derivatives may cause underperformance for CEF trading at discount, but they may become a major tool to make premium trading CEF outperform. 
Lastly, I examine the relationship between discounts and future performance conditional on derivative usage and try to make additional inferences about managerial performance hypothesis. In order to test my hypothesis, I estimate the following model:

$$
\text { PERF }_{i t}=\alpha+\beta_{1} D_{i, t-1}+\beta_{2} \text { PREM }_{i, t-1}+\beta_{3} D_{i, t-1} * \operatorname{PREM}_{i, t-1}+u_{i t}
$$

where PERFit is the monthly managerial performance (unconditional CAPM alpha calculated as stated in section 3 ) for CEF i starting in January of the year t. PREMi,t-1 is the premium (Note 17) of CEF $i$ at the end of month t-1. Di,t-1 is a dummy variable equal to one if the CEF uses derivatives in that month.

Table VIII. Premium and NAV Performance Relation Conditional on Derivatives

\begin{tabular}{ccccc}
\hline Variable & Intercept & $\mathrm{D}_{\mathrm{i}, t-1}$ & PREM $_{\mathrm{i},-1-1}$ & $\mathrm{D}_{\mathrm{i}, t-1}$ * PREM \\
\hline \multirow{2}{*}{ PERF $_{\mathrm{it}-1-1}$} & 207.44 & -3.809 & 0.054 & 0.022 \\
& $(8.01)^{* * *}$ & $(-0.27)$ & $(3.32)^{* * *}$ & $(0.31)$ \\
\hline
\end{tabular}

PERFit is the monthly managerial performance for CEF $i$ starting in January of the year t. PREMi,t-1 is the premium of CEF $i$ at the end of month $t-1$. Di,t-1 is a dummy variable equal to one if the CEF uses derivatives in that month. T statistics are in parentheses. There are 1,363 observations. $\mathrm{R}^{2}$ is 0.78 . Year dummies are not reported.

Estimated results are reported in Table VIII. I find a significant and positive relation (0.054) between CEF premium and their managerial performance. Hence, I can predict that, expected future managerial performance is priced by the investors and premium (discount) is a positive (negative) function of future performance.

On the other hand, a $1 \%$ increase in the derivative user CEF' premium makes $0.022 \%$ increase in alpha as opposed to non-user CEF'. As it is not statistically significant, I may infer that, when derivative usage is in question, future performance is not a predictor of current discounts/premia. This is consistent with my previous results revealing that derivative user CEF selling at discount are nominated for underperforming non-users. I concur that derivatives increase the opacity of portfolio management insomuch that investors are not able to set true prices in accordance with their evaluations of managerial future performance.

\section{Conclusion}

The CEF puzzle consists of the empirical finding that CEF shares sell at prices that are not equal to the per share market value of the assets the fund holds. One of the important explanations to the puzzle is the managerial performance hypothesis, which suggests that the market prices the fund manager's future performance. If future performance is expected to be bad, the CEF will sell at discount. My results support the managerial performance hypothesis since I find a significant and positive relation between $\mathrm{CEF}$ premium and their managerial performance. However, the main objective of this paper is to integrate derivative usage to the theory.

In the descriptive section of my study, I see that there is an increase in derivative use and fund managers are more decisive about using short equity derivatives to hedge and long currency derivatives to speculate. Moreover, a majority of derivative user funds trade at discount in the market. Following these descriptive results, I employ inferential analysis and firstly find that derivative user equity investor funds have more probability of discounts than non-user ones. I infer that, managers' equity holding preference lead them to use derivatives for hedging purposes in the expense of high performance. Secondly, I show that, level of performance is indifferent for derivative users and non-users, yet derivatives might cause underperformance for funds trading at discount. These findings complement each other in that although derivatives are negatively associated with discounts, this association turns into positive when equity investments and performance are considered. So, equity investments and hedging for them might cause underperformance, which might call for discounts for CEF. I lastly hypothesize that performance of derivative user CEF is a better estimator for discounts/premia than non-users. As to my main hypothesis, I find a significant and negative relation between expected future managerial performance and discounts, but, when derivative use is in question, this is not the case. Thus, I reject my complementary hypothesis in accordance with my findings and come up with the idea that the aforementioned positive relation seems not to be more explicit for derivative user CEF than non-users. I conclude that, derivative user CEF selling at discount underperforms non-users, probably due to heavily investing in and hedging against equity investments.

To the best of my knowledge, this paper is the first attempt to shed light on the managerial performance theory concerning use of derivatives by CEF. However, I see two notable limitations of this study. Firstly, my research handles $\mathrm{CEF}$ as if they are homogeneous while it is not the case. Some CEF are bond funds and some are equity funds or some CEF follow aggressive while some follow other strategies. It would be better to conduct a more comprehensive research. Secondly, I measure performance by using unconditional CAPM alpha only which may not be adequate for an in-depth analysis. Other return models such as conditional alpha and APT alpha would increase the robustness of the study. At this point, I leave these limitations to be removed in future studies. 


\section{References}

Ackermann, C., \& Ravenscraft, D. (1998). The Impact of Regulatory Restrictions on Fund Performance: A Comparative Study of Hedge Funds and Mutual Funds. (Unpublished Working Paper). Paris: University of Notre Dame.

Ackermann, C., McEnally, R., \& Ravenscraft, D. (1999). The Performance of Hedge Funds: Risk, Return, and Incentives. The Journal of Finance , 54 (3), 833-874. http://dx.doi.org/10.1111/0022-1082.00129

Arslan, Ö., Taşdemir, A., \& Pirgaip, B. (2010). How Do Turkish Mutual Funds And Investment Trusts Use Derivative Instruments? (Unpublished Working Paper). Hacettepe University, Ankara, Turkey.

Chay, J. B., \& Trzcinka, C. A. (1999). Managerial Performance and the Cross-Sectional Pricing of Closed-End Funds. Journal of Financial Economics, 52(3), 379-408. http://dx.doi.org/10.1016/S0304-405X(99)00013-6

Cherkes, M., Sagi, J., \& Stanton, R. (2008). A Liquidity-Based Theory of Closed-End Funds. Review of Financial Studies , 22(1), 257-297. http://dx.doi.org/10.1093/rfs/hhn028.

Dhar, K. (2012, March 1). SEBI and Collective Investment Schemes. (Working Paper). Hyderabad, India: NALSAR University.

Dimson, E., \& Minio-Paluello, C. (2002). The Closed-End Fund Discount. (Working Paper). USA: The Research Foundation of AIMR.

Fong, K., Gallagher, D. R., \& Ng, A. (2005). The Use of Derivatives by Investment Managers and Implications for Portfolio Performance and Risk. International Review of Finance, 5(1-2), 1-29. http://dx.doi.org/10.1111/j.1468-2443.2006.00049.x.

Garcia-Appendini, E., \& Rangel-Hilt, T. A. (2009). The Use of Derivatives in Italian Mutual Funds. (Working Paper). CAREFIN. Milan: University of Bocconi.

Johnson, L., \& Yu, W. (2004). An Analysis of the Use of Derivatives by the Canadian Mutual Fund Industry. Journal of International Money and Finance, 23(6), 947-970. http://dx.doi.org/10.1016/ j.jimonfin.2004.05.006

Koski, J. L., \& Pontiff, J. (1999). How Are Derivatives Used? Evidence From the Mutual Fund Industry. Journal of Finance , 54(2), 791-816. http://dx.doi.org/10.1111/0022-1082.00126

Lee, C. M., Shleifer, A., \& Thaler, R. H. (1990). Anomalies: Closed-End Mutual Funds. Journal of Economic Perspectives , 4(4), 153-164. http://dx.doi.org/10.1257/jep.4.4.153

Lee, C. M., Shleifer, A., \& Thaler, R. H. (1991). Investor Sentiment and the Closed-End Fund Puzzle. The Journal of Finance , 46(1), 75-109, http://dx.doi.org/10.1111/j.1540-6261.1991.tb03746.x.

Levy-Yeyati, E., \& Ubide, A. (1998, September). Crises, Contagion, and the Closed-End Country Fund Puzzle. (IMF Working Paper). U.S.: International Monetary Fund.

Mako, W., \& Sourrouille, D. (2010). Investment Funds in MENA. (Working Paper). The World Bank. U.S.: The World Bank.

Malkiel, B. G. (1995). The Structure of Closed-End Fund Discounts Revisited. Journal of Portfolio Management , 21, 32-38. http://dx.doi.org/10.3905/jpm.1995.409536.

Malkiel, B. G. (1977). The Valuation of Closed-End Investment Company Shares. Journal of Finance , 32, 847-859. http://dx.doi.org/10.1111/j.1540-6261.1977.tb01993.x.

Malkiel, B. G., \& Xu, Y. (2005). The Persistence and Predictability of Closed-End Fund Discounts. (Working Paper). Dallas: The University of Texas at Dallas. http://dx.doi.org/10.2139/ssrn.686981

OECD. (2005). White Paper on Governance of Collective Investment Schemes (CIS). OECD Journal (88), 137-167. http://dx.doi.org/10.1787/fmt-v2005-art5-en.

Pontiff, J. (1994). Closed-End Fund Premia and Returns: Implications for Financial Market Equilibrium. Journal of Financial Economics , 37, 341-370. http://dx.doi.org/10.1016/0304-405X(94)00800-G.

Richard, J. E., \& Wiggins, J. B. (2000). The Information Content of Closed-End Country Fund Discounts. Financial Services Review , 9, 171-181. http://dx.doi.org/10.1016/S1057-0810(00)00064-0

\section{Note}

Note 1. This is simply done by subtracting present value of liabilities from market price of assets held.

Note 2. See (Lee, Shleifer, \& Thaler, 1991), (Malkiel \& Xu, The Persistence and Predictability of Closed-End Fund Discounts, 2005) and the references therein 
Note 3. When managerial fees are taken into account as a subtractive, it'd rather refer the term as "managerial contribution" (Deaves \& Krinsky, 1994).

Note 4. See (Koski \& Pontiff, 1999) and the references therein.

Note 5. CEF (defined as securities investment trusts - please refer to Section 3 and 4.1.) are exempted from any tax requirements and it is forbidden to invest in illiquid assets in Turkey. Thus, it would be unreasonable for my study to go further taking tax liabilities and illiquidity of fund assets into consideration.

Note 6. Turkish Association of Institutional Investment Managers' of Turkey (TKYD) has been established in 1999 in order to promote incentives for the development and enhancement of institutional investment firms in Turkey (www.tkyd.org.tr).

Note 7. FINNET is a database company, which disseminates data about fund industry via its web site www.fonbul.com. The source of the data is TAKASBANK, the settlement and custody institution of ISE.

Note 8. REITs and VCITs disclose their NAVs quarterly and as they invest in illiquid assets (i.e. real estate, private equity) their NAVs are exposed to misvaluation.

Note 9. VCITs may prefer not to go public and offer their shares privately which in turn leads to the lack of market price information.

Note 10. They are allowed (for hedging only), but do not prefer as I observe.

Note 11. Actually, discounts are more in non-user group (88.9\%), but in total 50\% (12 divided by 24) of CEF trade at discount using derivatives at the same time.

Note 12. $\chi 2$ test is not appropriate since the expected frequency count for some cells in the contingency table is less than 5 .

Note 13. In goodness-of-fit tests, my model is significant, suggesting it does not fit the data. However, as I have an observation size of over 12,000, even very small divergencies of the model from the data would be flagged up and cause significance. Therefore, with observations of this size it is hard to find models that are parsimonious (i.e. that use the minimum amount of independent variables to explain the dependent variable) and fit the data. Other fit indices might be more appropriate. My pseudo $\mathrm{R}^{2}$ is pretty high in those terms.

Note 14. CEF return is the simple monthly average of daily NAV.

Note 15. Risk-free rate for a month is calculated as the monthly average of daily benchmark bond interest rates.

Note 16. TKYD, on daily basis, discloses benchmark fund indices for both bond (KYD Fund Indices Type A) and equity funds (KYD Fund Indices Type B). I use the former in my study. Although CEF portfolios invest in bond $(58,5 \%)$ more than equity $(39,5 \%)$ on average, most of the derivative instruments have equity indices as underlying assets, which makes us think that equity investments are better indicators of performance.

Note 17. The premium is computed as $\ln (\mathrm{MV} / \mathrm{NAV})$, where $\mathrm{MV}$ is the market value. A negative premium refers to a discount.

\section{$(\mathrm{cc}) \mathrm{EY}$}

This work is licensed under a Creative Commons Attribution 3.0 License. 